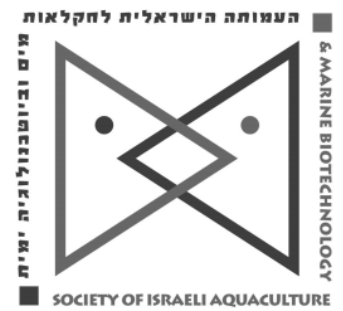

The IJA appears exclusively as a peer-reviewed on-line open-access journal at http://www.siamb.org.il. To read papers free of charge, please register online at registration form.

Sale of $I J A$ papers is strictly forbidden.

\title{
Effects of Feeding Frequency and Ration Level on Growth Performance and Non-Specific Immunity of Juvenile Turbot (Scophthalmus maximus) at Different Growth Stages
}

\author{
Keke Zheng, Mengqing Liang*, Wei Fang, Fanhua Kong, Houguo Xu
}

Laboratory for Marine Fisheries Science and Food Production Processes, Qingdao National Laboratory for Marine Science and Technology, Yellow Sea Fisheries Research Institute, Chinese Academy of Fishery Sciences, Qingdao, 266071, China

Keywords: ration level; feeding frequency; growth; feed utilization

\begin{abstract}
Four growth trials were carried out to optimize a feeding regime for turbot in industrial aquaculture systems at $15 \pm 0.5^{\circ} \mathrm{C}$. Six ration levels $(50 \%, 60 \%$, $70 \%, 80 \%, 90 \%$, and $100 \%$ ) of satiation were tested in trial I and five ration levels $(60 \%, 70 \%, 80 \%, 90 \%$ and $100 \%)$ of satiation were tested in trial III. For optimal feeding frequency, turbot were fed to satiation for $1 \mathrm{meal} / \mathrm{day}, 2$ meals/day, 3 meals/day in trial II, and 1 meal every other day, 1 meal/day, and 2 meals/day in trial IV. The average initial body weight of fish was $28.90 \pm 0.07 \mathrm{~g}$ for trials I \& II, and $181.75 \pm 1.05 \mathrm{~g}$ for trials III \& IV. Growth performance generally decreased and feed utilization increased with decreasing ration levels, while no significant differences were observed with small sized turbot fed to $80 \%, 90 \%, 100 \%$ levels of satiation, and with large sized turbot fed to $90 \% \& 100 \%$ levels of satiation. There was no increase in size heterogeneity with decreasing ration levels. Ration levels significantly influenced water quality. There were no significant differences in growth and feed efficiency among turbot fed with different feeding frequencies. Feeding small size turbot once a day and large size turbot once every other day at a ration level of $80 \%$ satiation is suggested for better feed utilization and less waste output.
\end{abstract}

* Corresponding author. E-mail: liangmq@ysfri.ac.cn 


\section{Introduction}

Turbot (Scophthalmus maximus) is a very valuable flatfish species in the family Scophthalmidae (order Pleuronectiformes). This species has been cultured in Europe since the 1970s and was introduced into China in 1990s. In recent years, China has become the leading turbot producer in the world with an annual amount of 50,00060,000 tons. The technology involved in the culture of turbot is well established, with a complete farm-raising cycle in land-based facilities. Maximum yields are not the only criterion; attention is also focused on cost effectiveness and sustainability. Feed represents around $60 \%$ of costs in intensive aquaculture and efficient use is therefore a prime economic factor in turbot aquaculture.

Feeding frequency and ration levels play a determining role in regulating feed intake, growth, and wastage. Manipulating feeding strategies are key to the economic success and sustainability of fish production (Cho and Bureau, 2002). There are limited studies related to feeding strategies and growth performance of turbot. Feeding frequency was found to affect growth, feed utilization, and body composition of juvenile turbot at low $\left(5-7.5^{\circ} \mathrm{C}\right)$ temperatures (Türker (2006). A factorial design of two feeding rates and three feeding frequencies was reported with juvenile black sea turbot (psetta maxima, linneaus, 1758) (Aydın et al. 2011). The present study was conducted to improve understanding of the effect of feeding frequency and ration levels on growth performance, feed utilization, waste production, and non-specific immunity of turbot (Scophthalmus maximus) at different growth stages.

\section{Materials and Methods}

Experimental design and maintenance of fish. The current study comprised four feeding trials (Trials I, II, III, and IV). Turbot were obtained from Yantai Tianyuan Aquatic Product Co., Ltd, Shandong, China and acclimated in a flow-through industrial rearing system for 2 weeks before onset of the trials. The average initial body weight of the fish was $28.90 \pm 0.07 \mathrm{~g}$ for trials I \& II, and $181.75 \pm 1.05 \mathrm{~g}$ for trials III \& IV. The fish were distributed randomly into fiberglass tanks (water volume $120 \mathrm{~L}$ in trials I, II, and $800 \mathrm{~L}$ in trials III, IV) with 20 fish per tank, and three replicate tanks for each treatment. Each tank was equipped with an air stone and supplied with $10 \mathrm{~L} / \mathrm{min}$ of deep well seawater with a salinity of $17-18 \mathrm{~g} / \mathrm{L}$. During the experiment, water temperature was constant at $15 \pm 0.5^{\circ} \mathrm{C}$; ammonia nitrogen was less than $0.1 \mathrm{mg} / \mathrm{L}$; dissolved oxygen was above 5 $\mathrm{mg} / \mathrm{L}$ and $\mathrm{pH}$ about 6.8 .

Experimental conditions are shown in table 1. Trials I \& III were carried out to investigate the optimum ration levels for turbot. Six ration levels were tested in trial I: $50 \%, 60 \%, 70 \%, 80 \%, 90 \%$ and $100 \%$ of satiation. Five ration levels were tested in trial III: $60 \%, 70 \%, 80 \%, 90 \%$ and $100 \%$ of satiation. Each trial had its own control and fish in the control group were hand-fed twice a day at 8:00 and 17:00 to apparent satiation ( $100 \%$ satiation), and daily feed intake was recorded. Ration levels of fish in the other experimental groups were determined based on the average feed consumption of fish in the control group. Trials II \& IV were conducted to test feeding frequency; turbot were fed to satiation for 1 meal per day (8:00), 2 meals per day $(8: 00,17: 00), 3$ meals per day $(8: 00,12: 00,17: 00)$ in trial II, and 1 meal every other day (8:00), 1 meal per day $(8: 00)$, and 2 meals a day $(8: 00,17: 00)$ in trial IV. Fish were offered commercial pellets (Fuzhou Haima Feed Co., Ltd) containing $46 \%$ protein, $15 \%$ lipid, $11 \%$ moisture and $13 \%$ ash. Particle size was $3 \mathrm{~mm}$ in trials I \& II, and $9 \mathrm{~mm}$ in trials III \& IV. All growth trials lasted for 45 days.

Table 1. Experimental conditions.

\begin{tabular}{llcl}
\hline & Initial body weight $(\mathrm{g})$ & Nr tanks & Treatment \\
\hline I & $28.90 \pm 0.07 \mathrm{~g}$ & 18 & $50 \%, 60 \%, 70 \%, 80 \%, 90 \% \& 100 \%$ satiation \\
II & $28.90 \pm 0.07 \mathrm{~g}$ & 9 & $1 \mathrm{meal} / \mathrm{day}, 2 \mathrm{meals} / \mathrm{day}, 3$ meals/day \\
III & $181.75 \pm 1.05 \mathrm{~g}$ & 15 & $60 \%, 70 \%, 80 \%, 90 \% \& 100 \%$ satiation \\
IV & $181.75 \pm 1.05 \mathrm{~g}$ & 9 & $1 \mathrm{meal}$ every other day, 1 meal $/$ day, 2 meals/day \\
\hline
\end{tabular}


Sampling. At the end of the trial, fish were starved for one day and then batch weighed. In trial $\mathrm{I}$, ammonia nitrogen $\left(\mathrm{NH}_{4}-\mathrm{N}\right)$, nitrite $\left(\mathrm{NO}_{2}-\mathrm{N}\right)$, and phosphorus $(P)$ concentrations in the water were tested in each tank 5 hours after feeding. The water flow was stopped before every water sampling. Concentration of ammonia nitrogen $\left(\mathrm{NH}_{4}-\right.$ $\mathrm{N})$ was measured with a Nessler reagent colorimetric determination kit. The concentration of nitrite $\left(\mathrm{NO}_{2}-\mathrm{N}\right)$ was measured with naphthylethylenediamine spectrophotometry, and the phosphorus concentration was measured with the molybdenum blue spectrophotometric method in accordance with Water and Wastewater Monitoring Analysis (State Environmental Protection Administration of China, 2002).

Analytical methods. The proximate composition of the experimental diets was determined by standard laboratory procedures of AOAC i.e. dry matter by drying at $105^{\circ} \mathrm{C}$ for five hours until constant weight was reached; crude protein ( $N * 6.25$ ) by the Kjeldhal method (UDK142 automatic distillation unit, VELP); crude lipid by petroleum ether extraction in a Soxtec ${ }^{T M}$ System (Soxtec ${ }^{T M} 2050$ system, Foss Tecator, Hoganas, Sweden); ash by incineration in a muffle furnace at $550^{\circ} \mathrm{C}$.

Statistical analysis. SPSS 16.0 for Windows software was used for data processing and statistical analysis. The homogeneity of variances was checked using the Levene's test. Data were compared by one-way ANOVA followed by Duncan's multiple range test. Differences between treatments were considered significant when $P<0.05$. All data are presented as means \pm S.E.M (standard error of the mean) of three replicates.

\section{Results}

Growth and feed utilization of turbot at different ration levels. No mortality was observed in the four feeding experiments. Specific growth rate (SGR), final body weight, and feed efficiency (FE), were significantly affected by the ration levels (Tables $2 \& 3$ ). In trial I, small size turbot fed to $80 \%, 90 \%$ levels of satiation showed no significant differences in their final body weight and SGR compared to fish fed to satiation $(P>0.05)$. Final body weight and SGR showed a linear decrease with decreasing ration levels from $70 \%$ to $50 \%$ satiation. In trial III, large size turbot fed at $90 \%$ satiation showed no significant differences in final body weight and SGR compared to fish fed to satiation $(P>0.05)$. The growth of the fish fed at $80 \%$ and $70 \%$ satiation was significantly lower compared to the fish fed to $100 \%$ and $90 \%$ levels of satiation $(P<0.05)$. Fish fed to $60 \%$ level of satiation had the lowest growth performance. There was no increase in size heterogeneity with the decreasing ration levels in both trials I and III, since the coefficients of variation for fish body weight remained unvarying throughout the growth trials.

Table 2. Effect of feeding ration levels on growth performance and feed utilization of turbot (initial body weight: $28.90 \pm 0.07 \mathrm{~g}$ ) in Trial I (Mean $\pm \mathrm{SE}$ ).

\begin{tabular}{|c|c|c|c|c|c|c|}
\hline & \multicolumn{5}{|c|}{ Feeding ration levels } & \multirow[b]{2}{*}{$50 \%$} \\
\hline & $100 \%$ & $90 \%$ & $80 \%$ & $70 \%$ & $60 \%$ & \\
\hline $\begin{array}{l}\text { Final body } \\
\text { weight }(\mathrm{g})\end{array}$ & $51.5 \pm 1.3^{\mathrm{a}}$ & $48.9 \pm 1.2^{\mathrm{ab}}$ & $48.9 \pm 1.2^{\mathrm{ab}}$ & $47.5 \pm 1.2^{\mathrm{bc}}$ & $44.9 \pm 0.4^{\mathrm{cd}}$ & $42.6 \pm 0.2^{d}$ \\
\hline $\begin{array}{l}\text { Specific } \\
\text { growth } \\
\text { rate }(\% / d)^{1}\end{array}$ & $\begin{array}{c}1.28 \pm 0.0 \\
6^{\mathrm{a}}\end{array}$ & $1.16 \pm 0.05^{\mathrm{ab}}$ & $1.16 \pm 0.06^{\mathrm{ab}}$ & $1.10 \pm 0.06^{\mathrm{bc}}$ & $0.97 \pm 0.02^{\mathrm{cd}}$ & $0.86 \pm 0.01^{d}$ \\
\hline $\begin{array}{l}\text { Feeding } \\
\text { rate }(\% / d)^{2}\end{array}$ & $\begin{array}{c}1.09 \pm 0.0 \\
2^{\mathrm{a}}\end{array}$ & $0.97 \pm 0.01^{b}$ & $0.91 \pm 0.01^{c}$ & $0.83 \pm 0.01^{\mathrm{d}}$ & $0.73 \pm 0.00^{e}$ & $0.64 \pm 0.00^{f}$ \\
\hline $\begin{array}{l}\text { Feed } \\
\text { efficiency } \\
(\%)^{3}\end{array}$ & $\begin{array}{c}113.9 \pm 3 \\
1^{a}\end{array}$ & $117.1 \pm 4.0^{\mathrm{ab}}$ & $124.5 \pm 6.7^{\mathrm{ab}}$ & $127.8 \pm 5.9^{\mathrm{ab}}$ & $131.3 \pm 3.1^{b}$ & $129.2 \pm 1.6^{\mathrm{b}}$ \\
\hline$\Delta \mathrm{CV}_{\mathrm{w}}(\%)^{4}$ & $\begin{array}{c}1.05 \pm 0.2 \\
1\end{array}$ & $1.02 \pm 0.09$ & $1.02 \pm 0.14$ & $1.01 \pm 0.22$ & $1.03 \pm 0.13$ & $1.06 \pm 0.25$ \\
\hline
\end{tabular}

Values with different superscripts in the same row are significantly different $(P<0.05)$.

${ }^{1}$ Specific growth rate $(S G R, \% / d)=100 \times\left[\ln W_{f}-\ln W_{i}\right] /$ feeding days, where $W_{f}=$ final wet body weight, $\mathrm{W}_{\mathrm{i}}=$ initial wet body weight.

${ }^{2}$ Feeding rate (\%body weight/day) $=100 \times$ total feed intake/[feeding days $\times\left(W_{i}+W_{f}\right) / 2$ ]

${ }^{3}$ Feed efficiency $(\%)=100 \times$ wet weight gain/dry feed intake

${ }^{4}$ Interindividual variations in body weight were assessed by calculation of the coefficient of variation: CV $(\%)=\left(\right.$ S.D. $\left.\times(\text { mean weight })^{-1}\right) \times 100$. Changes in the coefficient of variation during the growth period were calculated as: $\Delta \mathrm{CV}_{\mathrm{w}}(\%)=\mathrm{CV}_{\mathrm{t}=45} / \mathrm{CV}_{\mathrm{t}=0}$. 
Table 3. Effect of feeding ration levels on growth performance and feed utilization of turbot (initial body weight: $181.75 \pm 1.05 \mathrm{~g}$ ) in Trial III (Mean \pm SE).

\begin{tabular}{lccccc}
\hline & \multicolumn{4}{c}{ Feeding ration levels } \\
\cline { 2 - 6 } & $100 \%$ & $90 \%$ & $80 \%$ & $70 \%$ & $60 \%$ \\
\hline Final body weight $(\mathrm{g})$ & $266.49 \pm 3.25^{\mathrm{a}}$ & $266.15 \pm 1.99^{\mathrm{a}}$ & $260.46 \pm 1.73^{\mathrm{b}}$ & $254.71 \pm 0.57^{\mathrm{b}}$ & $244.31 \pm 3.17^{\mathrm{c}}$ \\
Specific growth rate $\left(\% \mathrm{~d}^{-1}\right)^{1}$ & $0.84 \pm 0.03^{\mathrm{a}}$ & $0.86 \pm 0.02^{\mathrm{a}}$ & $0.79 \pm 0.02^{\mathrm{b}}$ & $0.74 \pm 0.01^{\mathrm{b}}$ & $0.65 \pm 0.02^{\mathrm{c}}$ \\
Feeding rate $\% / \mathrm{d})^{2}$ & $0.71 \pm 0.03^{\mathrm{a}}$ & $0.63 \pm 0.00^{\mathrm{b}}$ & $0.56 \pm 0.00^{\mathrm{c}}$ & $0.50 \pm 0.00^{\mathrm{d}}$ & $0.44 \pm 0.00^{\mathrm{e}}$ \\
Feed efficiency $(\%)^{3}$ & $110.72 \pm 3.52^{\mathrm{a}}$ & $128.47 \pm 1.99^{\mathrm{b}}$ & $139.06 \pm 1.73^{\mathrm{c}}$ & $145.16 \pm 0.57^{\mathrm{c}}$ & $141.96 \pm 3.17^{\mathrm{c}}$ \\
$\Delta \mathrm{CV}_{\mathrm{w}}(\%)^{4}$ & $1.01 \pm 0.01$ & $1.01 \pm 0.05$ & $1.01 \pm 0.02$ & $1.01 \pm 0.02$ & $1.02 \pm 0.06$ \\
\hline
\end{tabular}

${ }^{1}$ Specific growth rate $(S G R, \% / d)=100 \times\left[\ln W_{f}-\ln W_{i}\right] /$ feeding days, where $W_{f}=$ final wet body weight, $\mathrm{W}_{\mathrm{i}}=$ initial wet body weight.

${ }^{2}$ Feeding rate (\%body weight/day) $=100 \times$ total feed intake/[feeding days $\left.\times\left(W_{i}+W_{f}\right) / 2\right]$

${ }^{3}$ Feed efficiency $(\%)=100 \times$ wet weight gain/dry feed intake

${ }^{4}$ Interindividual variations in body weight were assessed by calculation of the coefficient of variation: CV $(\%)=$ (S.D. $\times$ (mean weight) $\left.)^{-1}\right) \times 100$. Changes in the coefficient of variation during the growth period were calculated as: $\Delta \mathrm{CV}_{\mathrm{w}}(\%)=\mathrm{CV}_{\mathrm{t}=45} / \mathrm{CV}_{\mathrm{t}=0}$.

Feeding rate ranged from 1.09 to $0.64 \%$ of the fish body weight/day in trial I and from 0.71 to $0.44 \%$ in trial III. In both trials I and III, the FE first showed a linear increase with decreasing ration levels and then reached a plateau. Small turbot fed to satiation had a significant lower FE compared to fish fed to $50 \%, 60 \%$ satiation. Large turbot showed a significant increase of FE with decreasing ration levels from $100 \%$ to $80 \%$ satiation $(P<0.05)$.

Water quality. Ration levels significantly affected water quality in trial I (table 4). The concentration of ammonia nitrogen, nitrite, and phosphate decreased with decreasing ration levels $(\mathrm{P}<0.05)$. Fish fed to satiation had higher nitrite concentrations compared to fish fed $80 \%-50 \%$ satiation levels. Fish fed to $100 \%$, $90 \%$ of satiation had higher ammonia compared to fish fed $70 \%-50 \%$ of satiation. The concentration of phosphate was higher with fish fed $100 \%-70 \%$ satiation levels compared to others.

Table 4. Effect of feeding ration levels on rearing water quality in Trial I (Mean \pm SE).

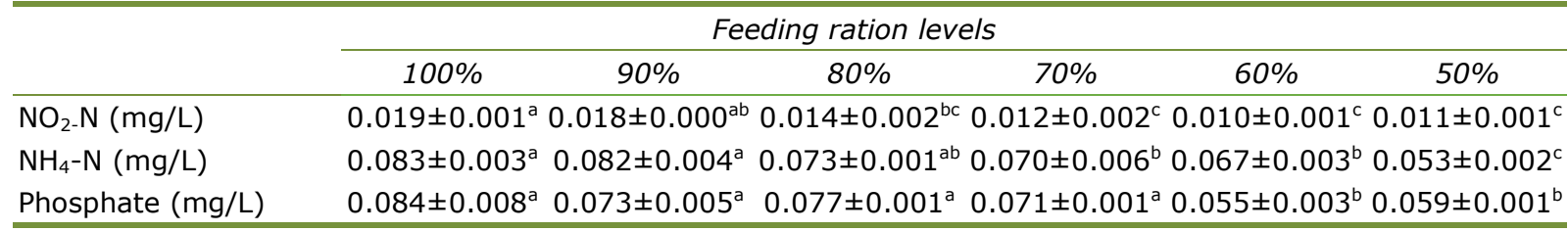

Values with different superscripts in the same row are significantly different $(P<0.05)$.

Growth and feed utilization of turbot at different feeding frequencies. There were no significant differences in final body weight, SGR, feeding rate, and feed efficiency among turbot fed at different feeding frequencies both in trial II and trial IV (tables $5 \& 6$ ) $(P>0.05)$. Feeding rate was $1.03-1.08 \%$ body weight/day in trial II and $0.63-0.70 \%$ body weight/day in trial IV.

Table 5. Effect of feeding frequency on growth performance and feed utilization of turbot (initial body weight: $28.90 \pm 0.07 \mathrm{~g}$ ) in Trial II (Mean $\pm \mathrm{SE}$ ).

\begin{tabular}{lccc}
\hline & \multicolumn{3}{c}{ Feeding frequency } \\
\cline { 2 - 4 } & 1 meal/day & 2 meals/day & 3 meals/day \\
\hline Final body weight $(\mathrm{g})$ & $49.8 \pm 0.3$ & $50.7 \pm 2.1$ & $52.0 \pm 2.6$ \\
Specific growth rate(\%/d) & $1.21 \pm 0.01$ & $1.24 \pm 0.09$ & $1.30 \pm 0.11$ \\
Feeding rate $(\% / d)^{2}$ & $1.03 \pm 0.02$ & $1.05 \pm 0.03$ & $1.08 \pm 0.06$ \\
Feed efficiency $(\%)^{3}$ & $115.2 \pm 1.0$ & $114.9 \pm 5.1$ & $117.4 \pm 3.7$ \\
\hline
\end{tabular}

${ }^{1}$ Specific growth rate $(S G R, \% / d)=100 \times\left[\ln W_{f}-\ln W_{i}\right] /$ feeding days, where $W_{f}=$ final wet body weight, $\mathrm{W}_{\mathrm{i}}=$ initial wet body weight.

${ }^{2}$ Feeding rate (\%body weight/day) $=100 \times$ total feed intake/[feeding days $\left.\times\left(W_{i}+W_{f}\right) / 2\right]$

${ }^{3}$ Feed efficiency $(\%)=100 \times$ wet weight gain/dry feed intake 
Table 6. Effect of feeding frequency on growth performance and feed utilization of turbot (initial body weight: $181.75 \pm 1.05 \mathrm{~g}$ ) in Trial IV (Mean \pm SE).

\begin{tabular}{lccl}
\hline & \multicolumn{3}{c}{ Feeding frequency } \\
\cline { 2 - 4 } & 2 meals/day & 1 meal/day & 1 meal/2 days \\
\hline Final body weight $(\mathrm{g})$ & $257.82 \pm 4.54$ & $256.28 \pm 3.29$ & $254.74 \pm 6.32$ \\
Specific growth rate $(\% / \mathrm{d})^{1}$ & $0.81 \pm 0.04$ & $0.79 \pm 0.04$ & $0.85 \pm 0.05$ \\
Feeding rate $(\% / \mathrm{d})^{2}$ & $0.70 \pm 0.03$ & $0.65 \pm 0.03$ & $0.63 \pm 0.01$ \\
Feed efficiency $(\%)^{3}$ & $115.23 \pm 7.10$ & $117.19 \pm 6.41$ & $119.70 \pm 8.47$ \\
\hline
\end{tabular}

${ }^{1}$ Specific growth rate $(S G R, \% / d)=100 \times\left[\ln W_{f}-\ln W_{i}\right] /$ feeding days, where $W_{f}=$ final wet body weight,

$\mathrm{W}_{\mathrm{i}}=$ initial wet body weight.

${ }^{2}$ Feeding rate $\left(\%\right.$ body weight/day) $=100 \times$ total feed intake/[feeding days $\left.\times\left(W_{i}+W_{f}\right) / 2\right]$

${ }^{3}$ Feed efficiency $(\%)=100 \times$ wet weight gain/dry feed intake

\section{Discussion}

Curvilinear regressions between ration levels and growth performance have been well demonstrated in fish (Wang et al., 2007; Zheng et al., 2015). Turbot showed a similar pattern in the current study. Small sized turbot fed with restricted ration levels of $80 \%$ satiation and large sized turbot fed with $90 \%$ of satiation showed no significant reduction in growth performance compared to fish fed to satiation. More importantly, turbot showed improved feed efficiency with restricted ration levels. In small sized turbot greatest FE was exhibited in fish fed $60 \%$ satiation level, and in large turbot greatest FE was in fish fed $70 \%$ satiation level. This is in agreement with another study on turbot fed $35 \%, 65 \%$, and $100 \%$ of satiation at different temperatures (Van Ham et al. 2003). The best feed conversion efficiency was found at $65 \%$ ration level. Many other studies have shown that the maximum FE was at feeding levels below that required for maximum growth (Storebakken and Austreng 1987; Wang et al. 2007; Blanquet and Oliva-Teles 2010). Conversely, there are studies showing that moderate feeding restrictions had no significant effect on feed efficiency ratio (Alanärä 1994; Azevedo et al., 1998). These studies with rainbow trout (Oncorhynchus mykiss) showed that feed efficiency was not significantly influenced by moderate feed restriction $(85 \%, 70 \%$, and as low as $50 \%$ of near satiation).

Feeding hierarchy formation is a major concern with restricted feeding in carnivorous fish farming, and leads to increased individual variation in fish body size and weight (Sæther and Jobling 1999). The restricted rations applied in the current study on turbot did not cause an increase in size heterogeneity, since there was little change in the coefficients of variation of weight (CV) during the trials and they were similar in all groups. This absence of a change in CV is in agreement with observations on turbot fed restricted rations (Sæther and Jobling, 1999; Van Ham et al., 2003). Therefore, it should be no impediment to apply restricted feeding rations in turbot farming for better feed utilization.

Overfeeding of turbot increases fish production costs and causes deterioration of water quality, which can eventually affect the growth and health of fish. Juvenile turbot growth may be depressed by usual ambient ammonia concentrations in intensive farming (Person-Le Ruyet, et al. 1997). It appears from the water quality results we monitored in trial I, that reducing ration levels to $70-80 \%$ of satiation in turbot could significantly reduce waste output. Concerns regarding the environmental effects of marine fish farms have arisen because fish farms release solid waste and discharge effluent directly into the water. Regulating feeding strategies reduces waste output and maintains better water quality. Further details about feeding strategies and the impact on environmental factors from on nitrogen and phosphorus waste output $(\mathrm{g} / \mathrm{kg}$ fish produced) should be investigated. It was found that feeding levels did not influence total solid wastes, solid and dissolved nitrogen waste, and phosphorus waste in rainbow trout at 6,9 , or $15^{\circ} \mathrm{C}$, but higher total solid waste and nitrogen waste were observed at the satiation level at $12^{\circ} \mathrm{C}$ (Alanärä 1994). 
Hand feeding is the most common method in turbot farming in China. Costs are higher when cultured fish are fed more frequently. Optimum feeding frequencies may change according to fish species and growth stages, also in different rearing conditions, including feed quality, feeding rate, and water temperature (Bin et al., 2014, Lee et al., 2000; Kestemont and Baras 2001). In low temperatures $\left(5-7^{\circ} \mathrm{C}\right)$, juvenile turbot between 15$25 \mathrm{~g}$ can be fed once every other day with without affecting growth (Türker, 2006). In the current study, we found that feeding small sized turbot (initial body weight $=28.9 \mathrm{~g}$ ) once a day and feeding large sized turbot (initial body weight $=181.7 \mathrm{~g}$ ) once every two days to satiation was enough to attain maximal growth. Similarly, feeding juvenile Black Sea turbot (initial body weight $=23.8 \mathrm{~g} \& 38.6 \mathrm{~g}$ ) once a day to satiation was sufficient to attain maximal growth (Aydın et al. 2011). Since food intake is related to stomach capacity, the time interval between feeding is also important for gastric evacuation and digestion rate (Brett, 1971). After satiation, the appetite in juvenile turbot was found to be closely related to the degree of stomach emptiness (Grove et al. 1985). When food is regularly available, juvenile turbot take feed steadily at a rate which equals $85 \%$ maximum fullness of their stomachs. Another study found that when fed continuously every three hours to apparent satiation under similar rearing conditions, juvenile turbots with an average body weight of $29 \mathrm{~g}$ showed a rhythm with a single peak once every 18 hours (Zheng et al. 2010). Protein nitrogen and energy assimilation efficiency in juvenile turbot remained unchanged irrespective of feeding rates and frequency when fed with energyrich diets (Grove et al., 1985). Our study is in agreement with this finding.

In conclusion, our results provide useful information in feed management for commercial turbot farmers. For better feed utilization and less waste output, in rearing temperatures of $15 \pm 0.5^{\circ} \mathrm{C}$, small sized turbot can be fed to $80 \%$ of satiation. Feeding small turbot (initial body weight $=28.9 \mathrm{~g}$ ) once a day, and large turbot (initial body weight $=181.7 \mathrm{~g}$ ) once every two days seems to be sufficient for effective growth.

\section{Acknowledgements}

This research was supported by Special Scientific Research Funds for Central Non-profit Institutes, Chinese Academy of Fishery Sciences (2014A08XK05).

\section{References}

Alanärä, A., 1994. The effect of temperature, dietary energy content and reward level on the demand feeding activity of rainbow trout (Oncorhynchus mykiss). Aquaculture $126,349-359$.

Aydın, I., Küçük, E., Sa̧aìn, T. and L. Kolotoğlu, 2011. The effect of feeding frequency and feeding rate on growth performance of juvenile black sea turbot (psetta maxima, linneaus, 1758). J Fish Sci 5, 35-42.

Azevedo, P. A., Cho, C. Y., Leeson, S. and D. P. Bureau, 1998. Effects of feeding level and water temperature on growth, nutrient and energy utilization and waste outputs of rainbow trout (Oncorhynchus mykiss). Aquatic Living Res 11, 227-238.

Bin C., Qi P., Bin W., Bo L., Wen L., Jian F., 2014. Effect of feeding frequency on growth rate, body composition and gastric evacuation of juvenile GIFT strain of Nile tilapia (Oreochromis niloticus), 8 pages. Isr J Aquacult.-Bamidgeh, 66.2014.973 .

Blanquet, I. and A. Oliva-Teles, 2010. Effect of feed restriction on the growth performance of turbot (Scophthalmus maximus L.) juveniles under commercial rearing conditions. Aquaculture Research 41, 1255-1260.

Brett, J. R., 1971. Satiation time, appetite, and maximum food intake of sockeye salmon (Oncorhynchus nerka). Journal of the Fisheries Board of Canada 28, 409-415.

Cho, C. Y. and D. P. Bureau, 2002. A review of diet formulation strategies and feeding systems to reduce excretory and feed wastes in aquaculture. Aquaculture Research 32, 349-360.

Ham, E. H. V., Berntssen, M. H. G., Imsland, A. K., Parpoura, A. C., Bonga, S. E. W. and S. O. Stefansson, 2003. The influence of temperature and ration on growth, feed conversion, body composition and nutrient retention of juvenile turbot (scophthalmus maximus). Aquaculture 217, 547-558. 
Kestemont, P. and E. Baras, 2001. Environmental factors and feed intake: mechanisms and interactions. Food intake in fish, 131-156.

Lee, S. M., Cho, S. H. and D. J. Kim, 2000. Effects of feeding frequency and dietary energy level on growth and body composition of juvenile flounder, Paralichthys olivaceus (Temminck \& Schlegel). Aquaculture Research 31, 917-921.

Morris Villarroel*, José Mario R. Alavriño, Javier López-Luna, Effect of Feeding Frequency and One Day Fasting on Tilapia (Oreochromis niloticus) and Water Quality, 6 pages. Isr. J. Aquacult.-Bamidgeh, [IIC:63.2011.609

Person-Le Ruyet, J., Delbard, C., Chartois, H. and H. L. Delliou, 1997. Toxicity of ammonia to turbot juveniles: 1 . effects on survival, growth and food utilisation. Aquatic Living Res 10, 307-314.

Grove, D. J., Moctezuma, M. A., Flett, H. R. J., Foott, J. S., Watson, T. and M. W. Flowerdew, 1985. Gastric emptying and the return of appetite in juvenile turbot, scophthalmus maximus, L., fed on artificial diets. J Fish Biol 26, 339-354.

Storebakken, T. and E. Austreng, 1987. Ration level for salmonids: II. Growth, feed intake, protein digestibility, body composition, and feed conversion in rainbow trout weighing 0.5-1.0 kg. Aquaculture 60, 207-221.

Sæther, B. S. and M. Jobling, 1999. The effects of ration level on feed intake and growth, and compensatory growth after restricted feeding, in turbot scophthalmus maximus. Aquacult Res 30, 647-653.

Türker A., 2006. Effect of feeding frequency on growth, feed consumption, and body composition in juvenile turbot (Psetta maxima Linaeus, 1758) at low temperature. Turk J Vet Anim Sci 30, 251-256.

Van Ham, E. H., Berntssen, M. H., Imsland, A. K., Parpoura, A. C., Bonga, S. E. W. and S. O. Stefansson, 2003. The influence of temperature and ration on growth, feed conversion, body composition and nutrient retention of juvenile turbot (Scophthalmus maximus). Aquaculture 217, 547-558.

Wang, Y., Kong, L. J., Li, K. and D. P. Bureau, 2007. Effects of feeding frequency and ration level on growth, feed utilization and nitrogen waste output of cuneate drum (Nibea miichthioides) reared in net pens. Aquaculture 271, 350-356.

Zheng, K. K., Deng, D. F., De Riu, N., Moniello, G. and S. S. Hung, 2015. The effect of feeding rate on the growth performance of green sturgeon (Acipenser medirostris) fry. Aquacult Nutr 21, 489-495.

Zheng, K. K., Fang, W., Kong, F. H., Chang, Q. and M. Q. Liang, 2010. Feeding rhythm and optimal feeding time for turbot Scophthalmus maximus L. juvenile. Fishery modernization 5, 26-30. 